\title{
Tourism Site Infrastructure, Visitor Patronage and Calabar Metropolis
}

\author{
Gloria Mayen Umukoro, Veronica Ebi Odey, Edisua Merab Yta \\ Department Of Modern Languages And Translation Studies University Of Calabar \\ Email: umukorogloria@gmail.com
}

\begin{abstract}
This study investigates the nature of tourism site infrastructure and how it affects patronage in Calabar Metropolis, Cross River State. The specific objectives of the study are to assess the security level, availability of leisure aid, recreation facilities, quantity and quality of historical artifacts, location ambiance, skilled tour guides and their effect on visitor patronage. The study is supported by Qualitative and inferential research design methods to ascertain the predictability of tourist patronage. A sample of one hundred and twenty-five (125) respondents were systematically selected for the study and questionnaires administered. The multiple nonlinear regression test statistic was deployed for validating the hypotheses developed for the study. Results show that security level, leisure and recreation, historical artifact and requisite accommodation were statistically significant in impacting a positive/direct influence on visitor patronage, while location ambiance and skilled tour guides were not statistically significant. It concludes that changes in visitor patronage can be accounted for by changes in tourist site infrastructure, but that location ambiance and skilled tour guides are not sufficient pull-factors for visitor patronage in Calabar Metropolis. It recommends among other things, government and private sector involvement in archeological research, security facilities, affordable accommodation for activities and oppressive use of mass media in portraying the historical significance of the area.
\end{abstract}

Key words: Tourism, infrastructure, patronage, location ambiance, tour guide.

\section{INTRODUCTION}

Economic diversification through non-crude oil-related activities has been the mantra of the current Mohammadu Buhari led democratic administration in Nigeria. The non-crude dimension in the policy includes among other things tourism, agriculture, solid mineral mining, entertainment and Information and Communication Technology (ICT). However, Worlu, (Worlu, Adekanbi, etc. all, 2015) observe that so far, these industries especially tourism have not received sufficient human and material support and/or investment from the government and private sector in Nigeria. This results in the slow pace of tourism development as an avenue for economic diversification. Accordingly, there is a dire need for adequate augmentation of tourism infrastructure in terms of leisure and recreation facilities, security, historical artifacts, location ambiance factors and tour guide personnel, (Umukroro \& Ohanyere, 2020; Ajake, 2015; Enemuo, Ajala, \& Offor, 2015; Oben, 2014; Odey, Ndobo, \& Endong, 2014; Yta, 2020) . This will aid in sustaining optimal visitor patronage during and after festive periods both in areas with high potency for perpetual visits and those without.

No doubt, Calabar metropolis possesses this potency of sustained tourist patronage, resulting from its rich historical heritage, botanical and wildlife conservation centres, Christmas festival, Diasporic Carnival and other traditional festivals. Foreign and indigenous tourist patronage is relatively at peak during festive periods, especially around December (Ajake, 2015). However, due to insufficient funding and mismanagement, most tourist site infrastructure is dilapidated and requires an upgrade to stimulate consistent patronage, examples include the famous Tinapa and Marina resorts. Consequently, it is also 


\section{Jurnal Office: Jurnal Pemikiran Ilmiah dan Pendidikan Administrasi Perkantoran \\ Vol. 6 No. 2, July - December 2020. Page 97-102}

observed that leisure and recreation facilities no longer meet international standards but rather operate on a mundane perspective. Historical artifacts are insufficient in both quality and quantity to sustain consistent patronage. The areas that were historically known for their role in the "slave trade era" have little or no tangible evidence left.

Another setback is in the area of research. While on the one hand there is insufficient funding in research that relates directly to archeology, on the other hand, there is an absence of research uptake. Furthermore, most tourist sites in the area are inadequately fortified with modern ambiance factors to include among other things attractive lighting, flowers, vehicle parking space, public relaxation sites, pedestrian paths and medical/health services. Also, the quality and quantity of skilled tour guides are perceived to lack adequate customer-responsive qualities. Based on this background, this study investigates tourist site infrastructure and its influence on patronage in Calabar Metropolis, Cross River State.

\section{METHOD}

The study adopted a quantitative research design. This approach was adopted because it aided the investigator to ascertain the predictability of visitor patronage in the study area based on the influence of six (6) independent variables that include security level, historical artifacts, leisure and recreation, location audience, your guide volume and accommodation quality.

The study is carried out in the Calabar metropolis. Calabar is composed of Calabar Municipality and Calabar South Local Government Areas. The area lies in the geographical coordinate of $4^{0} 34^{\prime} 27^{\prime \prime}$ North and $6^{0} 58^{\prime} 28^{\prime \prime}$ East. The area has an annual average Relative Humidity of eighty-five percent $(85 \%)$, four-hundred and six (406) $\mathrm{km}^{2}$ and a population of three hundred and seventy-one thousand and twenty-two $(371,022)$ inhabitants based on the result of the 2006 National Population Census.

The area has over thirty-two (32) tourist-visitor-ready sites, over three hundred and fifty (350) accommodation facilities that include hotels, guest houses, lodges, motels and resorts. A total number of four hundred and seventy-seven thousand six hundred and twenty-nine (477,629), visitors patronized these visitor-ready sites (CRSTB, 2016).

The sample of the study was significantly selected. Taro Yamane statistical estimation was deployed in aiming at a sample of one hundred and twenty-five (125) respondents. Four (4) tourist sites were used for the study. These include the National Museum, Ceropan Wildlife Conservation Centre, Marina Resort and Tinapa leisure Resort. However, the systematic sampling method was affected by contacting every three (3) visitors that entered the site.

Data were derived from both primary and secondary sources. Primary sources were gotten by questionnaire distribution, personal observation and interviews. The questionnaire drew heavily on respondents' opinions concerning the level of security, location ambiance, skilled tour guides, accommodation, historical artifact and leisure and recreation facilities. Secondary sources of data include historical data on visitor patronage from $1^{\text {st }}$ December 2016 to $31^{\text {st }}$ January 2017, extracted from Cross River State Tourism Bureau, and the various sites used for the study. This aided in comparing and setting a confidence interval.

Frequency count, mean and percentage were used for analyzing the data collected. Five hypothesis were developed and tested using the multiple non-linear Regression approach. The model specification is expressed thus:

$$
\mathrm{Y}=\mathrm{f}\left(\mathrm{x}_{1}, \mathrm{x}_{2} \ldots \ldots . \mathrm{x}_{\mathrm{n}}\right)
$$


Where:

$$
\begin{array}{ll}
\mathrm{Y} & =\text { Dependent Variable } \\
\mathrm{x}_{1}, \mathrm{x}_{2} \ldots \ldots \ldots \mathrm{x}_{\mathrm{n}} & =\text { Independent variables }
\end{array}
$$

The multiple linear model may be stated as;

$Y=b_{0}+b_{1}, x_{1}+b_{2}, x_{2}+b_{3}+x_{3}+b_{4}, x_{4}+b_{3} x_{3}+b_{6} x_{6}+$ et

Where:

$$
\begin{array}{ll}
\mathrm{Y} & =\text { Dependent variable } \\
\mathrm{b}_{0} & =\text { Vertical intercept } \\
\mathrm{b}_{1}-\mathrm{b}_{6} & =\text { Coefficient of predictors or independent variables } \\
\mathrm{X}_{1}-\mathrm{X}_{6} & =\text { Independent variables } \\
\text { et } & =\text { Random factor or error which affect } \mathrm{Y}
\end{array}
$$

Given that:

$$
\begin{array}{lll}
\mathrm{Y}= & \mathrm{VP}(\text { Visitor patronage) } \\
\mathrm{b}_{1}= & \mathrm{SL} & \text { (Security level) } \\
\mathrm{b}_{2}= & \text { LR } & \text { (Leisure and recreation) } \\
\mathrm{b}_{3}= & \text { HA } & \text { (Historical artefacts) } \\
\mathrm{b}_{4}= & \text { LA } & \text { (Location ambiance } \\
\mathrm{b}_{5}= & \text { TG } & \text { (Tour guide) } \\
\mathrm{b}_{6}= & \text { RA } & \text { (Requisite accommodation) }
\end{array}
$$

The model is explicitly expressed thus:

$$
\mathrm{Vpy}=\mathrm{b}_{0}+\mathrm{SLx}_{1}+\mathrm{LRx}_{2}+\mathrm{HAx}_{3}+\mathrm{Lax}_{4}+\mathrm{PGz}_{5}+\mathrm{RAx}_{6}+\mathrm{et}
$$

\section{Research hypotheses}

Six (6) hypotheses were developed based on the decomposition of tourist site infrastructure. They are sited in null $\left(\mathrm{H}_{0}\right)$ from below:
a. Security level has no significant effect on visitor patronage
b. Leisure and recreation do not affect visitor patronage
c. Historical artifacts do not influence visitor patronage
d. Location ambience has no significant effect on visitor patronage
e. Tour guide do not influence visitor patronage
f. Requisite accommodation has no effect on visitor patronage.

\section{RESULT AND DISCUSSION}

\section{Table 1.}

Multiple non-linear Regression result

\begin{tabular}{llll} 
& \multicolumn{3}{c}{ Multiple non-linear Regression result } \\
\hline Variable & Coefficient & Standard errors & t-value \\
SL $\left(\mathrm{x}_{1}\right)$ & 0.490 & 0.066 & $8.610^{* * *}$ \\
$\mathrm{LR}\left(\mathrm{x}_{2}\right)$ & 0.389 & 0.073 & $5.959^{* *}$ \\
$\mathrm{HA}\left(\mathrm{x}_{3}\right)$ & 0.249 & 0.071 & $4.321^{*}$ \\
\hline
\end{tabular}


$100 \mid$ Jurnal Office: Jurnal Pemikiran Ilmiah dan Pendidikan Administrasi Perkantoran

Vol. 6 No. 2, July - December 2020. Page 97-102

$\begin{array}{llll}\operatorname{LA}\left(x_{4}\right) & 0.130 & 0.037 & 1.687^{*} \\ \operatorname{TG}\left(x_{5}\right) & 0.032 & 0.002 & 1.701^{* *} \\ \operatorname{RA}\left(x_{6}\right) & 0.311 & 0.076 & 7.822^{* * *}\end{array}$

Model Summary and diagnostic statistic

R2

0.879243

Adjusted R2

0.880111

S. E of regression

0.055219

F- Value

$2.13 * *$

$2.13 * *$

$\begin{array}{ll}\mathbf{N B} & \\ * * * & \text { Represents significance at } 1 \% \text { probability } \\ * * & \text { Represents significance at } 5 \% \text { probability } \\ * & \text { Represent significance at } 10 \% \text { probability }\end{array}$

Table 1 above shows the multiple non-linear regression results for visitors' patronage, using six (6) predictors as tourist site infrastructure. The six (6) independent variables taken together were significant in impacting a positive variable on visitor patronage in the selected tourist site in Calabar metropolis with an outcome of $\mathrm{R}_{2}=0.879243$. The joint influence of the six (6) regressive on patronage outcome in the area was also found to be statistically significant at $\mathrm{F}=2.13, \mathrm{P}=0.000$. A critical examination of both beta coefficient security level $\left(\mathrm{x}_{1}\right)$, leisure and recreation $\left(\mathrm{x}_{2}\right)$, historical artifact $\left(\mathrm{x}_{3}\right)$, and requisite accommodation $\left(\mathrm{x}_{6}\right)$ gave $0.490,0.889,0.243$ and 0.311 unit, at $19 \%, 5 \%, 10 \%$ and $1 \%$ respectively. This indicates that security level, leisure and recreation, historical artifacts and requisite accommodation were statistically significant in impacting a positive/direct effect on visitor patronage. The implication is that an increase in $\mathrm{x}_{1}, \mathrm{x}_{2}, \mathrm{x}_{3}$ and $\mathrm{x}_{6}$ will induce a simultaneous increase in visitor patronage in the selected tourist sites in Calabar Metropolis. This result corresponds with the findings of Ajake, (2015) and Babatola, (2011) in their separate studies where evidence was found of a similar relationship between the destruction of image resources and patronage.

The coefficient location ambiance (x4) and tour guide (x5) were 0.130 and 0.32 units, at $10 \%$ and $5 \%$ probability respectively. Both variables were not statistically significant in imparting a positive effect on patronage. Indicating that location ambiance and the quality and quantity of tour guide was not a significant pull-factor for visitor patronage.

\section{CONCLUSION}

In synopsis, the model provided evidence that suggests that there is a bi-directional causality relationship between tourist site infrastructure and visitor patronage in the following sites: Marina Resort, National museum, Tinapa leisure Resort and Cercopan wildlife Conservation Resort. But among the variables of tourist site infrastructure, location ambience and skilled tour guide put differently were not considered as pull-factors for resistant visitor patronage. However, only security level, leisure and recreation, historical artifacts and requisite accommodation are the factors that induce visitor patronage.

\section{REFERENCE}

Ajake, A. (2015). Influence of Marketing Strategies on Tourists' Choice of Destination area in Cross River State, Nigeria. American Journal of Tourism Management, 4(3), 61-76.

Enemuo, O., Ajala, J., \& Offor, R. (2015). The Influence of Maintenance Culture in the Sustainability of Tourism Attractions in Obudu Mountain Resort. Journal of Tourism \& Hospitality, 4(5), 2-7. 
Gloria Mayen Umukoro, et. All: Tourism Site Infrastructure, Visitor Patronage 101

Oben, B. (2014). The African Mind and Globalization: Rethinking the Causes of Africa's Underdevelopment. Lwati: A Journal of Contemporary Research, 11(3), 20-27.

Odey, V. E., Ndobo, G. E., \& Endong, F. P. (2014). Effects of SMS Texting on the Writing Skills of University Students in Nigeria: Case of the College of Education Akamkpa. International Journal of Linguistics and Communication, 2(3), 2374-4803.

Umukroro, G. M., \& Ohanyere, L. O. (2020). "French is not My Language": Reactions By Foreign Languge Learners in Africa. A Journal of Contemporary Research, 17(2), 122-142.

Worlu, R. E., Adekanbi, T. O., Ajagbe, M. A., Isiavwe, D. T., \& Oke, A. O. (2015). Brand Identity of Tourist Destination and the Impact on Patronage. IIARD International Journal of Hospitality And Tourism Management, 1(3), 1-11.

Yta, E. M. (2020). Beyond Watt Market Roundabout Audiences: Redesigning Tourists Oriented Theatres in Calabar. Jurnal OOffice: Jurnal Pemikiran Ilmiah dan Pendidikan Administrasi Perkantoran, 6(1), 71-80. 
102 Jurnal Office: Jurnal Pemikiran Ilmiah dan Pendidikan Administrasi Perkantoran Vol. 6 No. 2, July - December 2020. Page 97-102 